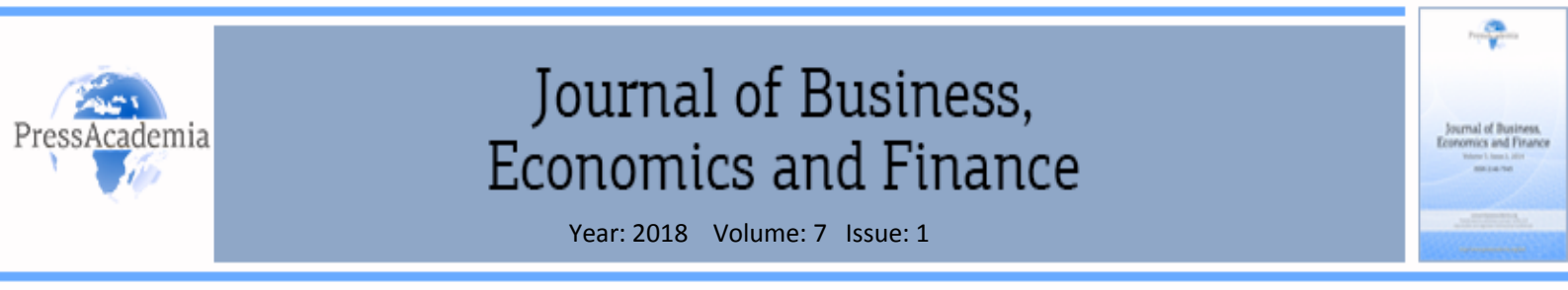

\title{
ADDRESSING POVERTY THROUGH MICROFINANCE: DOES IT WORK?
}

\author{
DOI: 10.17261/Pressacademia.2018.800 \\ JBEF- V.7-ISS.1-2018(11)-p.114-123
}

Ishtiaq Ahmad ${ }^{1}$, Rizwan Ahmed Satti ${ }^{2}$

${ }^{1}$ Public Schools and Colleges, Jutial Gilgit, Pakistan. seraph.ishtiaq@gmail.com , ORCID: 0000-0002-5733-9334

2 Allama Iqbal Open University , Islamabad, Pakistan. rizwan.ahmed@aiou.edu.pk, ORCID: 0000-0003-2168-9399

To cite this document

Ahmad, I., Satti, R. A. (2018). Addressing poverty through microfinance: does it work? Journal of Business, Economics and Finance (JBEF), V.7(1), p. 114-123.

Permanent link to this document: http://doi.org/10.17261/Pressacademia.2018.800

Copyright: Published by PressAcademia and limited licenced re-use rights only.

\begin{abstract}
Purpose- For the couple of decades microfinance has remained nucleus of developing nations to combat poverty. This paper aims to examine whether microfinance succeeded to reduce poverty? In this study poverty has been taken as analogous to 'extreme poverty'.

Methodology- Influence of microfinance in poverty eradication is investigated by comparing clients in first loan cycle with the clients of higher loan cycles. The data was analyzed in two ways; firstly, simple and straight forward descriptive analysis with simple univariate technique and secondly, empirical analysis is made by using binary logit model.

Findings- It is found that intermediation of microfinance did not only raise the income of borrowers but also lifted their spending over the loan cycles. The study also explores that over the successive loan cycles, possession of household durable item, spending on education, respond to the shocks and health status also improved. Clients in higher loan cycles managed to improve their social status.

Conclusion- Almost every examined poverty indicator indicates positive impact of microfinance on poverty eradication. However, various colors of poverty in the society do not allow us to cultimate the effectiveness of microfinance in poverty eradication.
\end{abstract}

Keywords: Business, gilgit, microfinance, poverty eradication, saving and consumption

JEL Codes: G21, 132, 016

\section{INTRODUCTION}

Poverty has reamained a perpetual apprehension of various nations and is often coined with the developing countries. Every possible effort is being exercised across the globe to combat poverty, as a result, the number of people living below poverty line has declined from 2 billion in 1990 to 705 million in 2015. This means that during these years 137,000 people exited the extreme poverty on daily basis (Roser and Ospina, 2017). Among various issues of the poor, lack of finance is the core issue, which resists them to participate in income generating activities; as a result situation becomes chronic with each passing day. In developing nations, microfinance is being used widely as a poverty reduction tool. By using microfinance, an economically handicapped member of a society is transformed into entrepreneurially active member who generates some income for his / her family (Samer et al., 2015; Mosley, 2010).

Use of microfinance and its impact studies have got more importance during the last decade (Kessy, 2009). These studies are conducted to measure the degree of success or failure of the program. Albeit most of the studies show positive impact of microfinance on poverty but its consistency is often questioned. Banerjee et al., (2013) pointed that by using microfinance, individuals with pre-existed business got expansion in it, whereas those without any business showed low propensity to start a new venture rather they increased non durable consumption. By exposing a poor person to microfinance, his /her condition is improved in short run, but when the given money is exhausted, condition of the poor becomes even more critical as he/she found him/her under additional burden of debt (Chowdhury et al, 2002; Yusuf et al, 2013). Maîtrot and Zarazúa (2017) nullifies the effectiveness of microfinance program, yet suggests it to be an important 
tool for the global efforts in the quest of poverty free world. Various hanging results of microfinance's impact on poverty, need further clarification. Present study is an effort in this regard.

World Bank has declared Pakistan as a poverty risk zone, where 60 percent of its population lives below poverty line (Basu, 2013). Poor people in Pakistan like other developing nations are also exposed to microfinance considering it a better way of combating poverty, but outreach of microfinance in the country is still limited. According to Pakistan microfinance Network (PMN) review (2010), in Pakistan microfinance outreach is approximately 2.4 million which is less than 10 percent of the probable market.

Present study is conducted in district Gilgit, located at the extreme north of Pakistan from where microfinance activities were initiated by Aga Khan Rural Support Program (AKRSP) in 1982 in the history of the country under AKRSP Model (Riaz et. al., 2012; Hussein, 2009). The Model was initially designed to form village and local social organizations with a group of 5 to 10 members for each organization. Members were brought under compulsory saving, against which small loans were provided to the members. Main aim of AKRSP model was to create saving behavior in poor people, particularly in women and to create for them a small business (AKF, 2012; Spoelberch and Shaw, 1987). The model was first applied to extreme poor of Gilgit, Pakistan because of its vulnerable poverty condition, where annual per capita income (Rs. 10, 312) of the inhabitant was slightly higher than half of the national average (Rs. 18,414) (AKRSP, 2001). The model was gradually modernized and given the modern microfinance shape by originating the First Microfinance Bank Limited in 2002 (AKRSP, 2001). Evidences from an early microfinance fed area will certainly help us to decide the success or failure of the program.

\section{LITERATURE REVIEW}

Handing some finance to the poor enables them to come out of the poverty, with this notion Shil (2009) intensifies the need of institutional modality of microfinance. Microfinance has the potential in renovating the poor and uplifting their status. It helped poor, particularly poor women to increase income (Swamy, 2015; Cheston and Khun, 2002). With his empirical analysis, Sivachithappa (2013) found that intervention of microfinance by self help groups (SHGs) has resulted increase in the level of income and assets of rural women of SHG. Ahmad and Satti (2017) came with the conclusion that women borrower managed to raise their income by indulging themselves in new ventures. Intermediation of microfinance to the poor women as studied by Samer et al., (2015) provided a way to earn some money for them. By examining general effects of microfinance institutions Imai and Azam (2011) concluded uplifting trend in food consumption and other poverty reducing indicators. Bauwin and Jbili (2017) investigated the growth rate of granted money over the loan cycle of Tunisian microfinance institutions and concluded a credulous relationship between the borrowers and microfinance institutions. They noticed heterogeneous increase in growth rate for women and men. The growth rate for women was much lower than for me. Using panel data from Bangladesh, Khandker (2015) examined the effect of microfinance on individuals and aggregate level. He found that as a result of microfinance, not only the life of borrowers improved but also the local economy boosted. Having access to the chunks of money, households managed to protect them against the risk and became able to deal with the shocks. The socio-financial intermediation also helped women to reduce vulnerability and to secure social assets and relationship of trust within the family and society (Wright et al., 1999).

Economic outcome of microfinance in the society reported to be marginal (Shirazi, 2012); only 3 percent poor managed to cross the poverty line. Poor borrowers made hardly 2 percent increase in their income to that of the 6 percent rise in non borrowers' income. According to Crepon et al., (2011), observed a very nominal push in normal consumption and very little effect on education, health and other indicators. They saw that individuals engaged in pre-economic activity showed decreasing trend not only in the consumption of non durable items but thr overall consumption also decreased, which shows expansion of economic activity and savings. Quite opposite results to that of Crepon et al., 2011 were seen by Banerjee et al., (2015) who nullified the notion 'miracle of microfinance' by carrying out the first randomized evaluation to see the impact of microfinance in a new market and concluded that households who already having any business got expansion in it, whereas those without any business remained failed to start a business. Overall impact of microfinance on poverty eradication is positive, but ultra poor borrowers remained failed to improve their status (Shirazi and Khan, 2009; Macissac, 1997). Through an in depth analysis of impact of microfinance in Sub-Saharan Africa, Rooyen et al., (2012) concluded that microfinance has a modest but not the consistent positive impact. They clarified that in some cases, microfinance increased poverty, disempowered the women and reduced children education as most of the borrowers failed to repay the loan due to diversion toward millennium development goals that led them to acute debt. Augsburg et al., (2012) conducted a study in Bosnia and Herzegovina and evaluated the impact of microcredit on poverty by using randomized controlled trial and found that access to microfinance helped individuals to start and expand small scale business. They observed a decline trend in saving of those who already had a business and more education, whereas the individuals with less education decreased their consumption. They also found increase in labour supply of young adults followed by the decrease in school enrollment.

Coleman (2006) investigated outreach and impact of microfinance programs in North East Thailand. He came to conclude that rich inhabitants significantly participate in the programs than the poor. Positive effects on household welfare had been 
reported for committee members; however, effects were insignificant in case of rank and file members. Due to various hurdles, the poor avoid to participate in the programs. Micro enterprise loan has a positive impact on poverty but failed to help the poor to exit poverty (Shaw, 2004). Small objective based funds via poverty targeted programs made AKRSP enabled to reduce severe poverty from 33 percent in 1991 to 5 percent in 2010 (AKRSP, 2012); conversely societies' marginalized segments failed in deriving optimal benefit from these projects. By conducting a specific survey of 2,274 households and 28 microfinance institutions in Philippine, Asian Development Bank (2007) reported that micro loaning did not help poor to escape from poverty, moreover poorest households who were finance with these loans did not show any sort of increase in household income. Nader (2007) did not see any significant effect of microfinance on health related issues. According to him, the borrowers after receiving microfinance depended upon free medical health insurance. Perception of harmony in the family was also found to have no significant association with microfinance. Hytopoulos (2011), concluded the failure of microfinance in human capital formation and strongly condemned the position of microfinance as working solution of global poverty. Maîtrot and Zarazúa (2017) scrutinized various impact studies of microfinance and termed it as an ineffective tool for poverty alleviation. According to him microfinance helped the poor to change their financial life positively in short run but remained failed to change their income, capital and assets on permanent and long term basis.

\section{DATA AND METHODOLOGY}

\subsection{Population and Sample Size}

The study is based on the primary data collected from the borrowers of First Microfinance Bank. Data was collected with a suitable sample size and random sampling technique from six rural areas of district Gilgit. Out of 156 Village/Local social organizations working in pre selected rural areas of the district (AKF, 2012), 49 were selected randomly from which 245 borrowers were selected in a specially designed random technique.

\subsection{Data Collection}

As per the nature of study, a detailed questionnaire was generated as a mechanism of data collection. All the questions were systematically set in order to cover every aspect that can be directly or indirectly affected by change in finance both in short run and in long run. Special care was taken to get demographical information in the beginning followed by the questions of borrowing and loan utilization, income, saving and consumption pattern, health, education and possession of durable items. Fixed set of responses were set in order to make process easy and time saving. Extensive interviews were conducted from selected clients from the pre selected village/local social organization in order to get their experience and activities as a part of the program.

\subsection{Data Analysis Techniques}

The data was analyzed in two ways. Firstly simple and straight forward descriptive analysis is made by using frequency distributions, mean, percentages and standard deviations for certain variables. Secondly, empirical analysis is carried by comparing control group (participant in first loan cycle) with sample clients (participant in two or more cycles). Loan cycle refers loan period which is one year for selected organization. If loan is paid back during the period, then the organization offers more loans to her clients for the next year and so on. We used Binary Logit Model to see the impact, because we had a primary data with fixed set of choices. We compared control group (first loan cycle $=0$ ) with treatment group (two or more loan cycles $=1$ ). Logit Regression is a quite strong technique with comparatively least constraints and analyzes a set of mix predictors.

\subsection{Poverty Line}

Setting a poverty line and to counnt the people under it (head count ratio) is a straightforward stradegy to measure poverty (Roser and Ospina, 2017). Poverty line was set on the basis of monthly income of household. Households whose monthly income was less than Rs. 5,500 (roughly US\$ 53) based on World Bank's latest poverty line of US\$ 1.90 per day were considered as extreme poor. Focusing on 'extreme poverty line' means capturing the most adverse and needy people of the society. The living conditions of those living just above the poverty line can also be hard and critical (Roser and Ospina, 2017). 
Table 1: Variables Used in Model

\begin{tabular}{lll}
\hline Variable & $\begin{array}{l}\text { Nature of } \\
\text { Variable }\end{array}$ & Detail of Variable \\
\hline $\begin{array}{l}\text { Demographic } \\
\text { Age }\end{array}$ & $\begin{array}{l}\text { Continuous } \\
\text { Binary }\end{array}$ & $\begin{array}{l}\text { Age of respondent in years } \\
=1 \text { if female, } 0 \text { otherwise } \\
\text { Education level of respondents }=1 \text { if have some } \\
\text { education, } 0 \text { otherwise } \\
=1 \text { if married, } 0 \text { otherwise }\end{array}$ \\
MDN & Binary & Family Size in numbers \\
NHH & Binary & Total Households Annual Income in rupees \\
THHI & Continuous & \\
Other Variables & Continuous & \\
Loan Cycle & Binary & $=1$ if two or more loan cycles, 0 if first loan cycle \\
Income & Binary & $=1$ if increased, 0 otherwise \\
Saving & Binary & $=1$ if increased, 0 otherwise \\
Spending & Binary & 1 if increased, 0 otherwise \\
Schooling & Binary & $=1$ if improved, 0 otherwise \\
Health Status & Binary & $=1$ if improved, 0 otherwise \\
Establishing Venture & Binary & $=1$ if established, 0 otherwise \\
\hline
\end{tabular}

\section{FINDINGS AND DISCUSSIONS}

The following section discusses the elucidation, discussion and analysis of the data obtained from clients of First Microfinance Bank. Data is interpreted both with descriptive and empirical analysis. To get the clear picture, poverty indicators like income, savings, expenditure, schooling, health status and establishing a venture are analyzed using logistic regression.

\subsection{Descriptive Analysis}

The population of 245 clients were divided into control group ( $N=42$, members of first loan cycle) and treatment group $(\mathrm{N}=203$, members of two or more loan cycles) following Johnson and Rogaly (1997). 44.2 percent clients in control group and 47.5 percent in treatment group managed to have their own house. Only $13.9 \%$ participants in first loan cycle have monthly income more than Rs. 5,500 (roughly US\$ 53) to that of $30.7 \%$ members in successive loan cycles. Average age for control group remained 32.9 years $(S D=6.62)$ and 36.2 years $(S D=8.07)$ for treatment group (Table 2$)$.

Table 2: Descriptive Analysis of Demography of Clients

\begin{tabular}{lll}
\hline Variables & Control Group $(\mathbf{N}=\mathbf{4 3})$ & Treatment Group (N= 202) \\
\hline Average Age & $32.9(\mathrm{sd}=6.62)$ & $36.2(\mathrm{sd}=8.07)$ \\
Family Size & 7.7 & 7.9 \\
Own Houses & $19(44.2 \%)$ & $96(47.5 \%)$ \\
Intermediate and Above & $20(46.4 \%)$ & $88(43.5 \%)$ \\
Secondary & $6(13.9 \%)$ & $39(19.3 \%)$ \\
Primary and Madarsa & $8(18.6 \%)$ & $27(13.4 \%)$ \\
Illiterate & $6(13.9 \%)$ & $40(19.8 \%$
\end{tabular}


Source: Generated by author based on survey data

\subsubsection{Ownership of Household Durable Items}

The accumulation or purchase of household durable items is directly affected with household income flux; therefore any change in income may likely to change household possession which can prove to be the impact gauge of microfinance mediation at the poor household. It is hypothesized that with microfinance interference household income raised which enhanced purchasing of durable items. Table 3 illustrates that $62.8 \%$ and $35.6 \%$ households of control and treatment groups respectively failed to buy any durable item, $32.6 \%$ and $35.2 \%$ from control and treatment group in the sequence did manage to purchase only single item; whereas $4.6 \%$ of control group and 29.25 of treatment group became able to add up their assts with two or more items. Interference of microfinance at household level came with a stronger positive effect on asset accumulation of treatment group to that of control group. Fig. 1 shows proclivity of households towards the purchase of various durable items after acquisition of microfinance. Microfinance mediation enabled almost $13 \%$ households in treatment group to buy a piece but land possession after the loan for control group was nil (Fig. 1)

Table 3: Change in Consumers Durable Items after Loan Mediation

\begin{tabular}{lcc} 
Change in durable items & Control Group (\% age) & Sample (\%age) \\
\hline Did not purchase any item & 62.8 & 35.6 \\
Purchased only one item & 32.6 & 35.2 \\
Purchased two or more items & 4.6 & 29.2 \\
Total & 100.0 & 100.0 \\
\hline
\end{tabular}

Source: Generated by the author from household survey

Figure 1: Household Trend in Possession of Durable Items

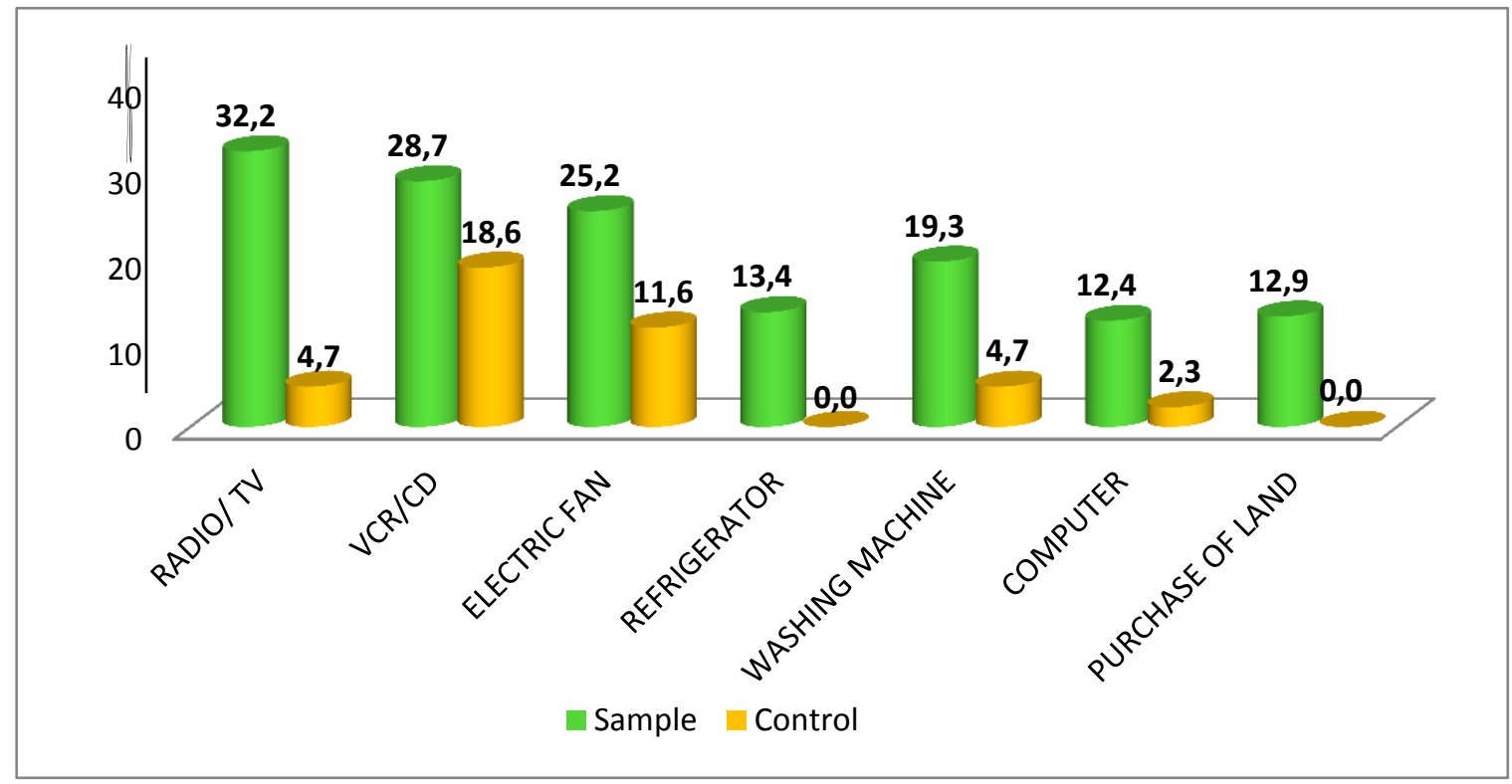




\subsubsection{Living with Shocks}

Natural shocks move parallel with life. Sudden shocks sometimes lead a huge financial disaster which often pushes those household back to poverty that have just made a step ahead and are in a transition line. Most often financial disaster come with such strength that a poor household cannot come out of its ferocious shock. In order to have the client's response towards shocks they were asked a few questions regarding nature of shock and respondent's response.

Table 4: Household Respond to Come out from Financial Shock

\begin{tabular}{lccc}
\hline Query & \multicolumn{2}{c}{$\begin{array}{c}\text { Control Group (N = 43) } \\
\text { Percentage (\%) }\end{array}$} & $\begin{array}{c}\text { Sample Group (N = 202) } \\
\text { Percent Points (\%) }\end{array}$ \\
\hline $\begin{array}{l}\text { Any major unexpected event in a } \\
\text { few months that led financial } \\
\text { burden }\end{array}$ & Yes & 11.6 & 23.3 \\
& No & 88.4 & 76.7 \\
& Used Savings & 20.0 & 31.9 \\
$\begin{array}{l}\text { How did you respond to come out } \\
\text { from the shock? }\end{array}$ & Borrowed & 60.0 & 48.9 \\
& Sold Assets & 20.0 & 19.1 \\
\hline
\end{tabular}

Source: Developed by the author from household survey

Table 4 notifies that $11.6 \%$ and $23.3 \%$ clients of control and sample groups respectively said that they had faced some shocks which lead greater financial burden. In responding to shock $20.0 \%$ (respondents who had faced financial burden) control group and about $32 \%$ of sample group said that they had used their savings to come out of the shock, $60 \%$ and about $49 \%$ respondents from control group and sample group respectively borrowed either from bank or from friends and relatives, exactly half $(50 \%)$ of shock faced clients made borrowings either from bank or from relatives, whereas $20 \%$ control group households and more than $19 \%$ sample group sold household assets to address the shock.

\subsubsection{Health and Medical Services}

Food, education, clothing and clean water are not the only issues faced by the poor, but an adverse effect of poverty is poorhealth condition. In order to explore the effect on health and access to medical services after microfinance mediation, respondents were interrogated regarding sick family members, way of treatment and affordability of medical expenses with a check query about status of health after loan.

Table 5: Status of Household Health and Medical Expenses

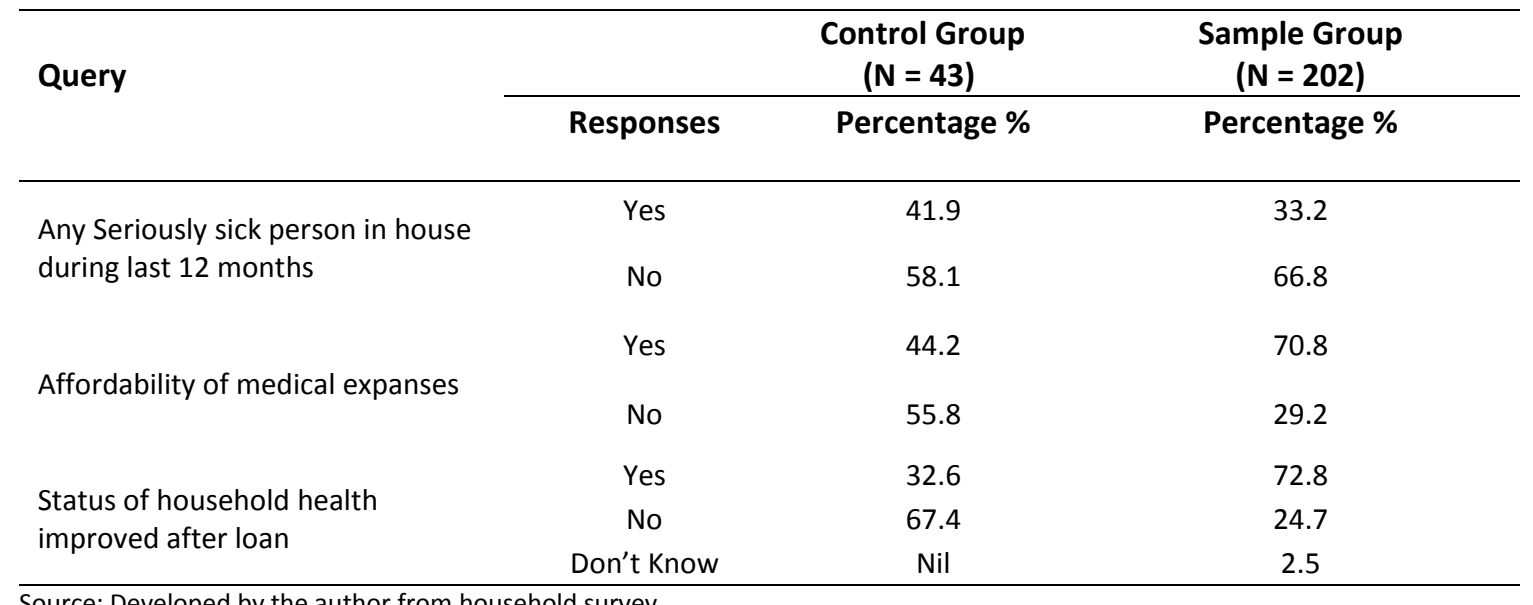

Source: Developed by the author from household survey 
Table 5 unveils that $41.9 \%$ and $33.2 \%$ respondents of control and sample group respectively responded to have seriously sick person (s) in the family during the last twelve months (from the time of interview). On inquiring about affordability of medical treatment, more than $44 \%$ of control group and about $71 \%$ of sample group were in a position to afford their medical expenses. $32.6 \%$ households in control group and $72.8 \%$ in sample group responded that their health status has been improved after getting microfinance. Thus microfinance impacted positively on household health; however, impact was very strong for sample group than control group.

\section{Figure 2: Various Medical Units where Household got Treatment}

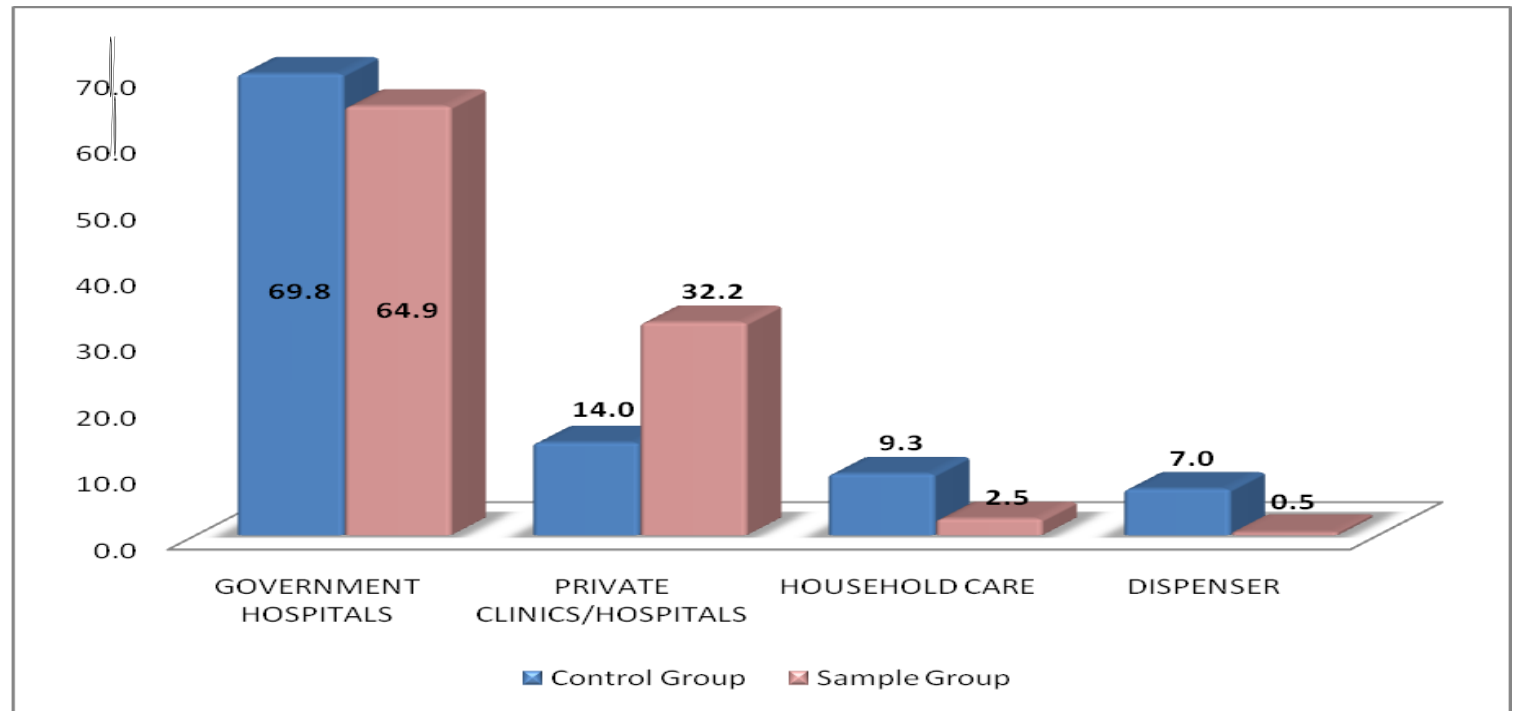

Figure 2 discloses health units from where household generally consult for medical examination whenever any member in the family becomes ill. It shows that $69.8 \%$ control group and $64.9 \%$ of sample group had access to government hospitals for medical checkup, $14 \%$ of control group and $32.2 \%$ of sample group moved to private clinics or private hospitals for their medical treatment, 9.3\% control group clients and 2.5\% sample group got treatment at household lever and $7 \%$ clients from control group and a fractional number $(0.5 \%)$ households of sample group consulted with dispenser for their medical treatment.

\subsubsection{Enhancement in Social Life}

Enhancement in social life can be determined by the expenditures made on different social activities. Microfinance clients were inquired about change in their spending behavior after joining the program.

Figure 3: Household Spending Pattern in Different Social Activities after Joining Microfinance

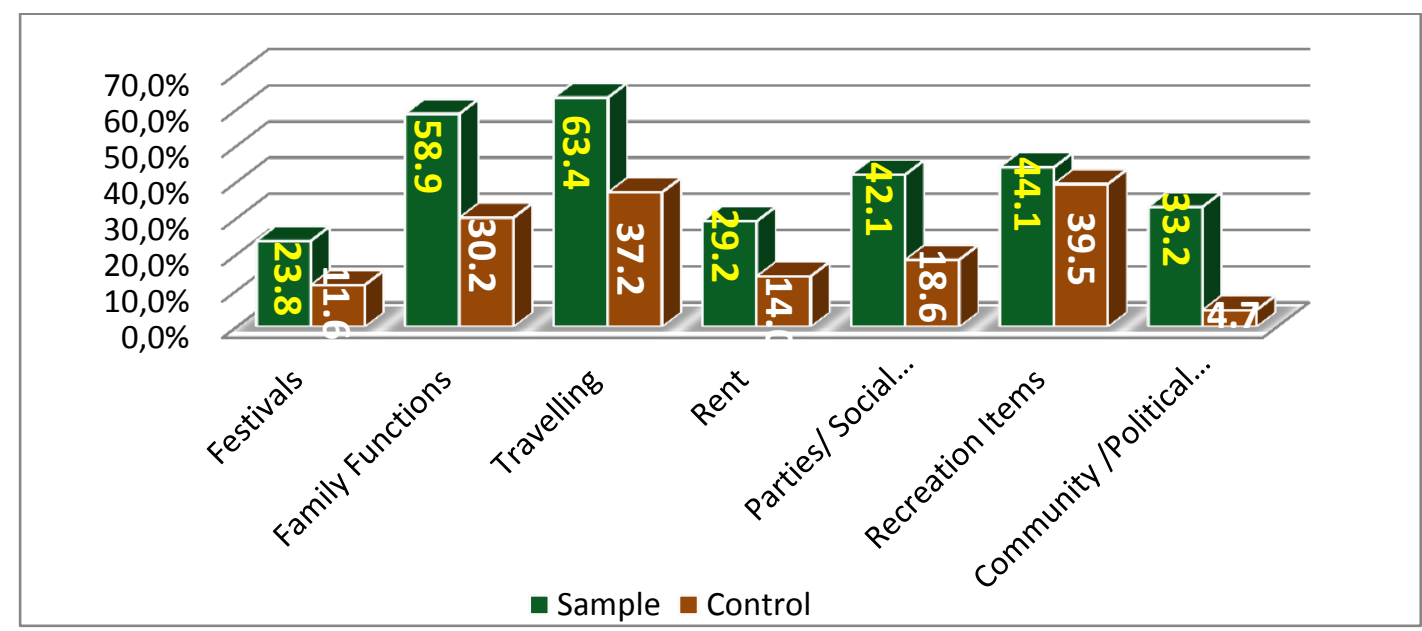


Figure-3 shows that spending on festivals had raised for $23.8 \%$ and $11.6 \%$ of sample and control groups respectively, almost $59 \%$ respondents from sample group and more than $30 \%$ respondents from control group increased spending on family functions, travelling expenditure had raised for $63.4 \%$ sample group clients and $37.2 \%$ for control group; Spending trend for $29.2 \%, 42.1 \%, 44.1 \%$ and $33.2 \%$ sample group clients had been risen on rent, social gathering/parties, recreation items and community/political affairs respectively, in sequence spending pattern for these items moved up for $14.0 \%, 18.6 \%, 39.5 \%$ and $4.7 \%$ of control group. The pattern shows that social life enhanced after microfinance mediation at household level and the impact was more inclined towards sample group.

\subsection{Empirical Analysis}

The way microfinance affects the household's life, can be seen by various factors like increase or decrease of income, saving, consumption, health, education and establishing a business. A healthy turn in these factor leads to poverty eradication conversely situation of the household becomes even more complex. The underlying assumption in providing microfinance to the poor is that it will provide some income for them to entangle themselves in any small business or income generating activity for a permanent source of income. For empirical analysis of the intervention of microfinance on underlying factors, logistic regression is applied having the membership in control group (first loan cycle $=0$ ) and treatment group (higher loan cycles $=1$ ).

Table 4: Logistic Regressions for Membership in Control Group and Treatment Group with Underlying Poverty Indicators

\begin{tabular}{lcccccc}
\hline Poverty Indicators & B & S.E & Wald & Df & Sig. & Ex(B) \\
\hline Income & 1.085 & 0.428 & 25.648 & 1 & 0.000 & 8.725 \\
Saving & -3.185 & 0.568 & 31.449 & 1 & 0.010 & 3.824 \\
Spending & 1.593 & 0.402 & 15.705 & 1 & 0.000 & 4.917 \\
Schooling & 0.883 & 0.388 & 5.165 & 1 & 0.023 & 2.417 \\
Health Status & 1.119 & 0.344 & 10.58 & 1 & 0.001 & 3.062 \\
Establishing Venture & 1.480 & 0.398 & 13.831 & 1 & 0.014 & 4.395 \\
Cox and Snell R & & & & 0.132 & & \\
NagelKerke R & & & & 0.172 & & \\
\hline
\end{tabular}

Source: Developed by author based on survey data

The analyzed poverty indicators found comprehensively significant. Ex(B) of 4.395 for establishing a venture reveals that over the successive loan cycles, borrowers did establish a business for themselves which turned to be a permanent source of income. The odds ratio of 3.824 and 4.917 for saving and spending respectively show that the participants managed to enjoy a better life status after exposition to microfinance (Table 4). Status of schooling seems to narrate the similar impact as it is found significant at $0.023<0.05$. Income generation looks much better with higher value of odds ratio.

Findings of the study seem to remain parallel with Shirazi (2012) and Crepon et al (2011) in terms of poverty reduction but did not stand with them in terms of business creation. Finding of the study regarding new venture did not stand with Banerjee et. al., (2015) who resulted with failure of microfinance to help poor creating any venture. However, present study is carried in extreme rural areas to that of urban areas as studied by Banerjee et. al., (2015) with first randomized approach of impact study of microfinance. Cultural values, norms of the society and the behavior of people usually affect the results. Apart from current results, it is quite still difficult to reach a conclusion regarding effectiveness of microfinance as poverty reducing agent; because poverty in any society keeps its existence in multiple shapes (Roser abd Ospina, 2017). An extensive study for higher poverty lines and an amalgamated study of multiple societies with larger variables is needed to access to the core of the issue.

\section{CONCLUSION}

Poverty is one of the core issues of third world countries. In rural areas, situation goes beyond alarming condition. Various tools have been developed to resolve the issue, among which, microfinance has been used to be an effective tool and is often exercised by developing nations. 
The focus of this study is to seek the impact of microfinance program on poverty alleviation. In order to portray the role of microfinance in true sense, the study is carried in district Gilgit, where microfinance activities were started for the first time in 1982 by Aga Khan Rural Support Program (AKRSP) (Riaz et. al., 2012; AKRSP, 2001). Poor, particularly the poor women are vulnerable and economically inactive almost in every society; therefore microfinance is usually targeted to make them capable to produce some income (Spoelberch and Shaw, 1987). Considering the fact, data was collected from 245 clients of First Microfinance Bank through household survey of six rural and far flung areas of district Gilgit Pakistan. Analysis of the study was made using control group (for first loan cycle) and treatment group (for higher loan cycles).

The study compared respondents of control group to that of treatment group to analyze impact of microfinance on poverty. Data was analyzed both with simple descriptive technique and logistic regression. The study finds that after inclusion of microfinance, the clients manage to start a venture with the subsequent loan cycles. Clients in treatment group expanded their income and raised consumption beside uplifting the schooling. Possession of durable household items did also improve along with improvement in health condition and access to health units. Clients in higher loan cycles did spend more on social activities and respond to the schock in a better way, which indicates an upward shift in social status. Hence observed poverty indicators found improved. Existence of various colors of poverty in any society makes it impossible to pass a strong notion regarding the issue. To pass a solid statement regarding success and failure of microfinance in addressing poverty needs further study with amalgamated cultural values, larger variables and higher poverty lines is needed. Comparative studies of the issue in rural and urban areas for various variables in same time frame may also be helpful to decide the corner.

\section{REFERENCES}

AKF. (2012). AKRSP: Annual Report 2012, Monitoring, Evaluation and Research. Section. http://www.akdn.org/publications.asp

AKRSP.(2001). Microfinance Programme Operations Review 2000.

http://www.mixmarket.org/sites/default/files/medialibrary/20501.308/AKRSP-AR-00.pdf

Ahmad, I., and Satti, R. A. (2017). Empowerment through Microfinance: Where does it tilt? A Case Study of District Gilgit, Pakistan. Imperial Journal of Interdisciplinary Research (IJIR), 3(2),1153-1160.

Asian Development Bank. Economics, Re, and Asian Development Bank. Development Indi. (2011). Key Indicators for Asia and the Pacific 2011. Asian Development Bank.

Augsburg, B., De Haas, R., Harmgart, H., and Meghir, C. (2012). Microfinance at the margin: experimental evidence from Bosnia and Herzegovina.

Banerjee, A., Chandrasekhar, A. G., Duflo, E., and Jackson, M. O. (2013). The diffusion of microfinance. Science, $341(6144), 1236498$.

Banerjee, A., Duflo, E., Glennerster, R., and Kinnan, C. (2015). The miracle of microfinance? Evidence from a randomized evaluation. American Economic Journal: Applied Economics, 7(1), 22-53.

Basu, K. (2013). Shared prosperity and the mitigation of poverty: in practice and in precept. World Bank Policy Research Working Paper, (6700).

Bauwin, M., and Jbili, W. (2017). Loyalty, trust, and glass ceiling: The gender effect on microcredit renewal (No. 2017/101). WIDER Working Paper.

Cheston, S., and Kuhn, L. (2002). Empowering women through microfinance. Draft, Opportunity International. http://storage.globalcitizen.net/data/topic/knowledge/uploads/201101311419705.pdf

Chowdhury, M. J. A., Ghosh, D., and Wright, R. E. (2005). The impact of micro-credit on poverty: evidence from Bangladesh. Progress in Development studies, 5(4), 298-309.

Coleman, B. E. (2006). Microfinance in Northeast Thailand: Who benefits and how much? World development, 34(9), 1612-1638.

Crepon, B., Devoto, F., Duflo, E., and Pariente, W. (2011). Impact of microcredit in rural areas of Morocco: Evidence from a Randomized Evaluation. MIT Working Paper.

De Spoelberch, G., and Shaw, R. D. A. (1987). A Model: The Aga Khan Rural Support Program. Challenge, 29 (6), $26-31$

Hussein, M. H. (2009). State of Microfinance in Afghanistan. Institute of Microfinance (InM).

http://inm.org.bd/wp-content/themes/inm/pdf/Afghanistan.pdf

Hytopoulos, E. (2011). The impact of microfinance loans on children's educational attainment in rural thailand. Economics.

Imai, K. S., and Azam, M. S. (2012). Does microfinance reduce poverty in Bangladesh? New evidence from household panel data. Journal of Development Studies, 48(5), 633-653 
Kessy, S. (2009). Microfinance and enterprises performance in Tanzania: Does gender matter. Repositioning African Business and Development for the 21st Century, 125-131.

Khandker, S. R. (2005). Microfinance and poverty: Evidence using panel data from Bangladesh. The World Bank Economic Review, 19(2), 263-286.

Maclsaac, N. (1997). The role of microcredit in poverty reduction and promoting gender equity: A discussion paper report to CIDA.

Maîtrot, M., and Niño-Zarazúa, M. (2017). Poverty and wellbeing impacts of microfinance: What do we know?.

Max Roser and Esteban Ortiz-Ospina (2017) - ‘Global Extreme Poverty'. Published online at OurWorldInData.org.

https://ourworldindata.org/extreme-poverty.

Mosley, P. (2001). Microfinance and poverty in Bolivia. Journal of Development Studies, 37(4), 101-132.

Nader, Y. F. (2008). Microcredit and the socio-economic wellbeing of women and their families in Cairo. The Journal of SocioEconomics, 37(2), 644-656.

PMN. (2013). Microfinance Review 2013; www.brecorder.com/mfr2013

Riaz, A., Muhammad, S., Ashraf, I., and Zafar, M. I. (2012). Role of Punjab rural support program in improving economic conditions of rural women through micro financing. Pak. J. Agri. Sci, 49(2), 211-216.

Samer, S., Majid, I., Rizal, S., Muhamad, M. R., and Rashid, N. (2015). The impact of microfinance on poverty reduction: Empirical evidence from Malaysian perspective. Procedia-Social and Behavioral Sciences, 195, 721-728.

Shil, N. C. (2009). Micro finance for poverty alleviation: A commercialized view. International Journal of Economics and Finance, 1 (2), 191.

Shirazi, N. S. (2012). Targeting and Socio-Economic Impact of Microfinance: A Case Study of Pakistan. Islamic Economic Studies, $20(2), 1-28$.

Shirazi, N.S. and Khan, A.U. (2009). Role of Pakistan Poverty Alleviation Fund's Microcredit in Poverty Alleviation: A Case Study of Pakistan, Pakistan Economic and Social Review, Vol. 47, No. 2, 215-228.

Sivachithappa, K. (2013). Impact of Micro Finance on Income Generation and Livelihood of Members of Self Help Groups-A Case Study of Mandya District, India. Procedia-Social and Behavioral Sciences, 91, 228-240.

Swamy, V. (2014). Financial inclusion, gender dimension, and economic impact on poor households. World Development, 56, 1-15.

Van Rooyen, C., Stewart, R., and De Wet, T. (2012). The impact of microfinance in sub-Saharan Africa: a systematic review of the evidence. World Development, 40(11), 2249-2262.

Wright, G. A., Kasente, D., Semogerere, G., and Mutesasira, L. (1999). Vulnerability, risks, assets and empowerment. The impact of microfinance on poverty alleviation: Final report. http://www.academia.edu/download/31091259/1730_file_01730.pdf

Yusuf, M.B.O., Shirazi, N. S., and Ghani, G.M. (2013). The Impact of Pakistan Poverty Alleviation Fund on Poverty in Pakistan: An Empirical Analysis, Middle-East Journal of Scientific Research 13 (10), 1335-1344. 